\title{
STUDI POTENSI BRAIN GAIN SEBAGAI INOVASI REGENERASI PELAKU AGRIBISNIS DI DATARAN TINGGI CIANJUR
}

\author{
Iwan Setiawan ${ }^{1}$, Sumardjo $^{2}$, Arif Satria ${ }^{2}$ dan Prabowo Tjitropranoto ${ }^{2}$ \\ ${ }^{1}$ Staf Pengajar Fakultas Pertanian Universitas Padjadjaran \\ ${ }^{2}$ Staf Pengajar Fakultas Ekologi Manusia Institut Pertanian Bogor \\ E-mail: iones73@yahoo.com
}

\begin{abstract}
ABSTRAK. Penelitian ini bertujuan untuk mendeskripsikan proses brain gain, karakteristik pelaku brain gain, faktor penarik dan pendorong brain gain, serta kemandirian pelaku brain gain. Untuk itu digunakan desain kualitatif dengan metode studi kasus. Tujuh orang pelaku muda agribisnis terdidik dan berkeahlian ditempatkan sebagai informan dan dipilih secara purposive. Observasi, wawancara mendalam dan diskusi terfokus dilakukan di dataran tinggi Kabupaten Cianjur mulai bulan Oktober-Desember 2013. Data dianalisis secara deskriptif dengan model interaktif. Hasil penelitian mengungkap bahwa: (1) berdasarkan prosesnya, brain gain terbagi dalam kategori primer dan sekunder yang terbangun secara swakarsa sebagai bentuk adaptasi, dengan motif dan tujuan yang relatif berbeda; (2) karakteristik pelaku brain gain primer berbeda dengan pelaku brain gain sekunder; (3) Pelaku brain gain memiliki pengetahuan yang luas, bersikap positif dan berketerampilan tinggi, terutama dalam agribisnis sayuran untuk pelaku primer, agribisnis non sayuran untuk pelaku sekunder; (4) kedua pelaku relatif mandiri, namun pelaku brain gain sekunder lebih mandiri; (5) tindakan brain gain pelaku primer cenderung dipengaruhi faktor pendorong eksternal dan faktor penarik struktural, sedangkan pelaku sekunder cenderung dipengaruhi faktor pendorong internal dan faktor penarik kultural-natural; dan (6) model brain gain terintegrasi potensial bagi inovasi regenerasi pelaku agribisnis. Perlu diteliti lebih lanjut kesiapan beragribisnis dari kedua pelaku.
\end{abstract}

Kata Kunci: brain gain, inovasi regenerasi, pelaku muda agribisnis

\section{STUDY BRAIN GAIN AS A POTENTIAL FOR INNOVATION IN AGRIBUSINESS REGENERATION ACTORS PLATEAU CIANJUR}

\begin{abstract}
This study aims to describe the brain gain process, characteristics of brain gain actors, push and pull factors of brain gain, and interdependence of brain gain actors. Qualitative design was used for the case study method. Seven youth agribusiness educated and skilled placed as informants were purposively. Observation and in-depth interviews conducted in the highlands of Cianjur Regency start from October to December 2013, data were analyzed descriptively with an interactive model. The results of the study reveal that: (1) based on the process, the brain gain is divided into primary categories and secondary which as spontaneous grown up as a form of adaptation, with the motive and purpose are both relatively distinct; (2) the characteristics of the different actors of primary brain gain with a perpetrators of secondary; (3) The perpetrator of brain gain has extensive knowledge, positive attitude and highly skilled, especially in agribusiness vegetables for the primary actors and agribusiness non veg for secondary actors; (4) two relatively interdependent actors, but secondary actors more self-sufficient; (5) measures brain gain primary actors driving factors likely influenced the external and structural pull factors, while secondary actors tend to be influenced by internal factors and pull factors driving culturalnatural; and (6) integrated of brain gain model potential for regeneration innovation. Needs to be further investigated agribusiness readiness of both the actors.
\end{abstract}

Key word: brain gain, regeneration innovation, youth agribusiness

\section{PENDAHULUAN}

Ancaman terhadap keberlanjutan pertanian Indo-nesia semakin nyata, terutama bersumber dari faktor sumberdaya manusia pelaku utamanya yang sebagian besar tua (aging agriculture). Penelitian Sumardjo (1999) di Provinsi Jawa Barat mengungkap bahwa rerata usia petani adalah 49 tahun, 40 persennya berusia lebih dari 50 tahun (Agussabti, 2002) dan 20 persen diantarannya berusia 60-80 tahun (Setiawan, 2012; Sadono, 2012). Usia yang tua identik dengan kualitas dan daya saing yang rendah, yang dicirikan dengan kondisi pendidikan, kesehatan, psikologis, karsa dan produktivitas kerja yang rendah. Penyebab utamanya adalah stagnasi regenerasi, baik akibat rendahnya minat dan penilaian generasi muda terhadap sektor pertanian (under value) maupun akibat derasnya laju migrasi tenaga-tenaga muda (brain drain). Ironi, padahal regenerasi merupakan prasyarat keberlanjutan (Capra, 2002).

Berbagai pendekatan untuk meregenerasi petani telah diterapkan di Indonesia, termasuk mengirimkan tenaga terdidik ke pedesaan (seperti: sarjana pendamping petani, fasilitator pembangunan dan sarjana membangun desa). Namun karena sifatnya temporer (keproyekan), bias kepentingan dan aksinya lebih bersifat mobilisasi (remigration), maka proses dan hasilnya tetap jauh dari harapan. Bahkan, tidak sedikit yang gagal mencapai tujuan, sehingga mempertajam under value generasi dan mempercepat laju brain drain. Oleh karena itu, diperlukan alternatif inovasi pendekatan regenerasi petani yang lebih menjamin keberlanjutan, salah satunya adalah brain gain, 
yakni membalik pemuda-pemuda berpendidikan dan berkeahlian dari perantauan (luar negeri, perkotaan, pulau dominan) ke daerah asalnya (dalam negeri, pedesaan dan pulau tertinggal).

Brain gain merupakan inovasi pendekatan regenerasi yang sedang menjadi perbincangan hangat di Eropa Timur, Asia, Amerika Selatan dan Afrika Utara. Secara riil, dalam 20 tahun terakhir, brain gain telah terbukti sukses diterapkan di Inggris Raya, Cina, India, Taiwan, Korea Selatan dan Afrika Utara (Kupets, 2011; $\mathrm{Hu}$ et al, 2012). Oleh karena itu, Konferensi Uni Eropa (2007) merekomendasi brain gain sebagai pendekatan baru untuk memecahkan persoalan ketimpangan SDM dan pembangunan. Pada praktiknya, brain gain ada yang dirancang oleh pemerintah atau swasta dan ada yang berjalan secara swakarsa (Hunger, 2002; Stark, 2004; Schiff, 2005; Beine et al., 2008). Friedman (2009) dan Mahbubani (2011) menyatakan "untuk sampai pada kebijakan brain gain, pemerintah China,Taiwan dan India memulainya secara gradual dari identifikasi, deskripsi, analisis dan pemetaan kasus brain gain yang berjalan secara swakarsa".

Secara empiris, fenomena brain gain juga terjadi di Indonesia, namun belum dilembagakan secara formal sebagai sebuah kebijakan dan pendekatan regenerasi. Salah satun kasus brain gain yang menarik untuk dikaji adalah kehadiran pelaku-pelaku muda agribisnis terdidik dan berkeahlian di dataran tinggi Kabupaten Cianjur Jawa Barat. Berbeda dengan daerah dataran tinggi lainnya di Jawa Barat, apalagi dengan zona agroekosistem sawah dan lahan kering berbasis palawija, sekitar $85 \%$ petani di dataran tinggi Cianjur berusia muda. Sekitar $25 \%$ diantaranya adalah pemuda-pemuda terdidik dan berkeahlian yang lama merantau ke perkotaan dan luar negeri, namun karena berbagai faktor akhirnya kembali ke desa, baik untuk bekerja maupun berwirausaha agribisnis. Hal yang menarik untuk dikaji, kembalinya mereka dari perantauan yang dilakukan secara swakarsa, paradoks dengan tren migrasi yang banyak dilakukan kaum muda pedesaan. Penelitian ini bertujuan untuk: (1) memetakan proses brain gain; (2) mendeskripsikan karakteristik pelaku brain gain; (3) menganalisis perilaku pelaku brain gain; (4) menganalisis kemandirian pelaku brain gain; (5) menganalisis faktor pendorong dan penarik brain gain; dan (6) merumuskan model intervensi brain gain.

\section{METODE}

Penelitian ini menggunakan paradigma konstruktivisme, desain kualitatifdanmetodestudikasus. Penelitian dilakukan di Dataran Tinggi Kabupaten Cianjur selama tiga bulan, mulai 01 Oktober 2013 sampai 31 Desember 2013. Ada dua jenis data yang dikumpulkan dan dianalisis, yaitu data primer dan data sekunder. Data prmer diperoleh dari subjek utama (informan), yakni pelaku brain gain (pelaku muda agribisnis) yang berjumlah tujuh orang dan dipilih secara sengaja (purposive). Data penelitian dikumpulkan melalui teknik observasi partisipatif, wawancara mendalam, diskusi terfokus dan studi dokumentasi, kemudian dianalisis dengan menggunakan model interaktif, baik secara prosedural maupun secara teknis. Data-data yang terkumpul divalidasi otentisitasnya dengan validitas kumulatif, validitas komunikatif, validitas argumentatif, dan validitas ekologis. Selain itu, peneliti juga memperhatikan derajat kepercayaan dan kebergantungan (dependability).

\section{HASIL DAN PEMBAHASAN}

\section{Proses Brain Gain}

Fenomena brain gain di dataran tinggi Cianjur relatif lebih tinggi daripada fenomena brain darin-nya. Hal itu terjadi karena: (1) sayuran dataran tinggi dihargai pasar, sehingga lebih menjanjikan secara sosial ekonomi; (2) usahatani sayuran memerlukan perawatan yang intensif, sehingga tidak banyak memberi kesempatan (waktu luang) kepada para pelakunya untuk bermigrasi; (3) usahatani sayuran cepat menghasilkan, sehingga lebih menjamin pendapatan; (4) pasar sayuran tersedia di desa (seperti tengkulak, bandar, supplier, subterminal agribisnis); (5) secara fisik-teknis, kondisi jalan dan layanan transportasi dari dan ke luar desa kurang mendukung, sehingga memperlambat laju mobilitas; dan (6) sebagian tenaga muda desa terserap oleh perusahaan agribisnis dan usaha-usaha alternatif dalam desa (seperti packing house, agribisnis strobery).

Pada kenyataannya, brain gain tidak hanya dilakukan oleh tenaga muda berkualitas, tetapi juga oleh tenaga tua terdidik dan berkeahlian (seperti pensiunan). Konteks terdidik tidak selalu identik dengan pendidikan formal yang tinggi, tetapi juga pendidikan non formal (seperti kursus tani, magang, sekolah lapang dan pelatihan agribisnis). Seperti halnya pelaku brain gain muda, pelaku brain gain tua juga positif bagi pembangunan di pedesaan. Secara umum, usaha yang dikembangkan pelaku brain gain di dataran tinggi tidak hanya sayuran, tetapi juga agribisnis non sayuran dan usaha non pertanian (seperti: bengkel, konter handphone, salon, toko saprotan). Pelaku brain gain agribisnis pun ada yang primer (usahatani sayuran) dan sekunder (usaha non sayuran, termasuk agroindustri).

Motif pelaku brain gain primer cenderung pada pengembangan usaha agribisnis sayuran dataran tinggi (terutama kentang, tomat, cabe, bawang daun, kol, wortel), sedangkan pelaku sekunder cenderung pada usaha alternatif, seperti peternakan (domba, kelinci, lebah), agribisnis sutera, budidaya jamur, sayuran organik, budidaya bunga, bisnis stroberi, radio komunitas, cyber extension, packing house, pelestarian lingkungan dan agro-ekowisata (Gambar 1). Baik pelaku brain gain primer maupun sekunder, sama-sama melalui tahapan proses adaptasi untuk dapat menyesuaikan diri dengan 
lingkungan agribisnis pedesaan. Tujuan keduannya pun relatif sama, yakni better agribusiness, better living dan better community. Berbeda dengan pelaku brain gain sekunder, pelaku primer cenderung kurang peduli terhadap lingkungan (better environment).

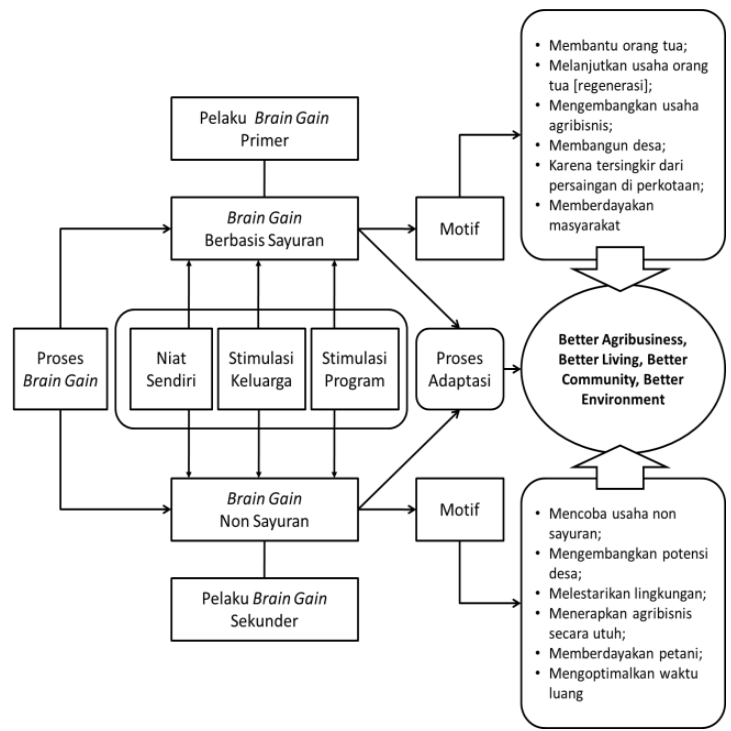

Gambar 1. Model Proses Brain Gain Pelaku Agribisnis di Dataran Tinggi Cianjur

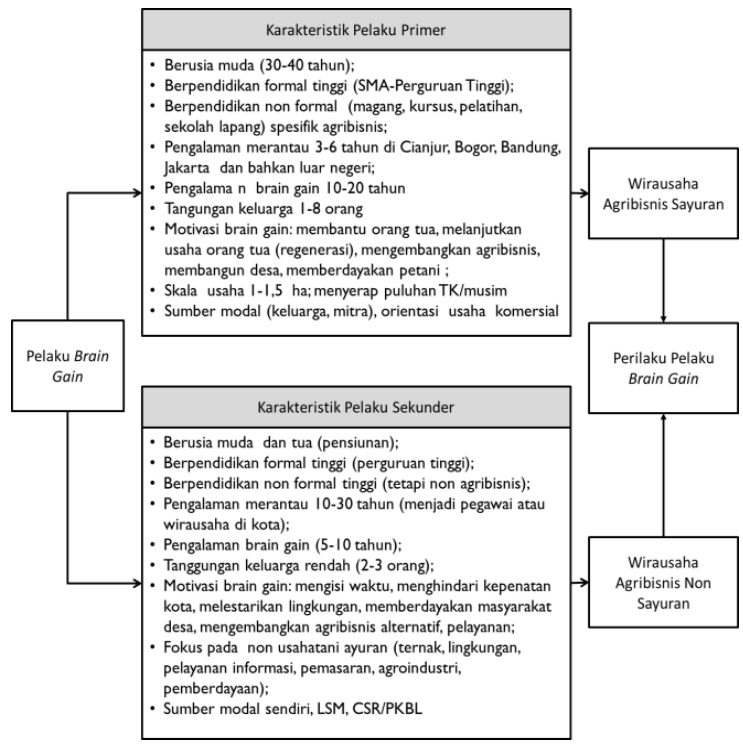

Gambar 2. Model Karakteristik Personal Pelaku Brain Gain

\section{Karakteristik Pelaku Brain Gain}

Pada umumnya, pelaku brain gain tergolong pada kelompok elit desa (anak petani kaya dan keluarga kelas menengah), berusia muda, berpendidikan relatif tinggi, pernah merantau (baik sekolah, bekerja, magang, maupun mengikuti pelatihan), kosmopolitan dan akses terhadap jejaring (bisnis, pasar, informasi), adaptif, berani (baik dalam mengambil keputusan, melakukan perubahan, maupun mencoba inovasi), berorientasi pasar dan lebih mampu berorganisasi. Selain itu, juga memiliki rasa ingin tahu (curiousity) yang tinggi, responsif terhadap inovasi, kreatif dan inovatif (dalam wirausaha, pasar, jejaring), akses terhadap permodalan, mampu bermitra dan mengelola organisasi, serta bermotivasi tinggi.
Namun, karakteristik pelaku brain gain primer berbeda dengan pelaku brain gain sekunder (Gambar 2). Selain lebih cerdas, karakteristik usahanya pun cenderung berbeda dengan petani pada umumnya, baik komoditas, model pengelolaan maupun inovasinya. Secara umum, karakteristik pelaku brain gain di dataran tinggi Cianjur tidak jauh berbeda dengan temuan Faiz (2007), Ha et al. (2009) dan Warker (2009) di Asia, Eropa, Amerika Selatan dan Afrika Utara.

Secara umum, 75 persen pelaku agribisnis di dataran tinggi Cianjur adalah tenaga muda, namun sekitar 60 persennya berpendidikan dasar. Tingginya minat dan partisipasi pemuda dalam beragribisnis di dataran tinggi menegaskan bahwa apa yang dikemukakan oleh Soewardi (1978) dan Collier et al., (1996) tentang petani di Jawa yang rata-rata berusia tua, ternyata tidak berlaku di dataran tinggi. Tesis Kurnia (1995) tentang kapilaritas sosial (yakni pandangan orang tua yang tidak menghendaki anak-anaknya untuk terjun pada sektor pertanian), juga tidak berlaku di dataran tinggi.

\section{Perilaku Pelaku Brain Gain}

Pelaku brain gain di dataran tinggi Cianjur dapat digolongkan menjadi tiga tipe. Pertama, pelaku yang telah lama meninggalkan desa dengan tujuan belajar atau sekolah formal; Kedua, pelaku yang meninggalkan desa beberapa tahun dengan tujuan belajar atau sekolah non formal (seperti magang kerja, magang usaha agribisnis, magang di institusi pertanian), baik di dalam negeri (seperti di Lembang, Garut, Pangalengan) maupun di luar negeri (seperti di Jepang); dan Ketiga, pelaku yang lama meninggalkan desa untuk bekerja pada pekerjaan non pertanian, kemudian kembali ke desa ketika sudah memasuki usia pensiun. Ada dua alasan yang mendasari mereka kembali ke desa. Pertama, dari awal sudah berniat untuk berusaha di desa (melanjutkan usaha orang tuanya); dan Kedua, karena jenuh dan sulit bersaing di perkotaan.

Berdasarkan perilakunya, pelaku braingain dapat dikelompokan menjadi tiga. Pertama, kelompok pelaku dengan perilaku yang fokus pada usahatani sayuran. Kelompok ini memandang usahatani sayuran sebagai potensi desa yang diwariskan secara turun temurun. Pandangan ini otomatis mewarnai pengetahuan, sikap dan keterampilan lainnya, baik dalam berorganisasi, berwirausaha, berbisnis maupun berjejaring. Sehingga semuanya serba berkaitan dengan sayuran dataran tinggi. Kecenderungan perilaku agribisnisnya masih bias usahatani (on-farm). Orientasinya sangat komersial dan cenderung eksploitatif (maksimalisasi keuntungan), sehingga kurang peduli terhadap lingkungan. Fenomenanya terlihat nyata dari penggunaan input (pupuk, pestisida) kimia yang masih tinggi.

Kedua, kelompok pelaku dengan perilaku yang lebih berwawasan agribisnis dan berwawasan lingkungan. Potensi desa dilihat secara luas berdasarkan 
perspektif global, sehingga tidak lagi terfokus pada sayuran dataran tinggi, terutama pada areal konservasi. Kelompok ini berpandangan bahwa dataran tinggi tidak "dikutuk" untuk sayuran, tetapi potensial juga untuk hortikultura non sayuran, agroforestri, peternakan dan agroindustri. Usahatani tetap dijalankan, tetapi menggunakan pendekatan yang lebih ramah terhadap lingkungan, seperti hutan rakyat dan pengelolaan hutan bersama masyarakat (PHBM).

Ketiga, kelompok pelaku yang berwawasan integratif, yang memadukan potensi lokal (biodiversity, endogenous knowledge, landscape, social capital) dengan perkembangan kemodernan dan tren global. Kelompok ini tidak hanya berorientasi bisnis, tetapi juga memperhatikan keseimbangan ekologis. Usaha yang dikembangkannya adalah pertanian terpadu, seperti agrowisata, agroeducation, desawisata, kampung kreatif dan ekowisata. Beberapa diantaranya mengembangkan radio komunitas dan lembaga swadaya yang bergerak dalam advokasi dan pelayanan informasi lingkungan (Gambar 3).

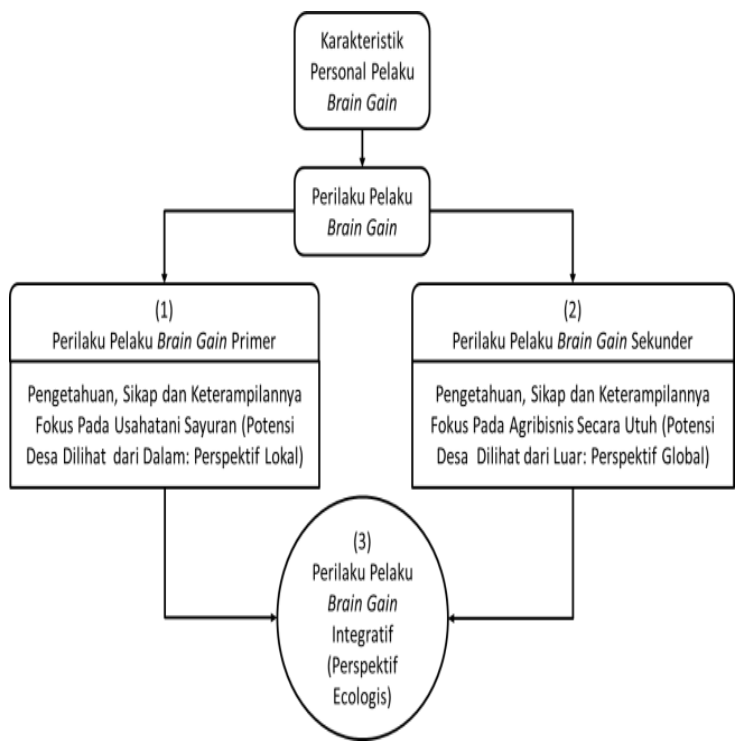

Gambar 3. Model Perilaku Pelaku Brain Gain Primer, Sekunder dan Tersier

Perilaku pelaku brain gain, baik yang primer maupun sekunder, dipengaruhi oleh pandangan mereka terhadap dirinya (konsep diri), oleh orang lain yang sangat dekat dengan dirinya (significan orthers) dan oleh kelompok rujukannya (reference group). Menurut pelaku primer, usahatani sayuran yang diwariskan secara turun temurun telah terbukti menyejahterakan petani. Dari sayuran, banyak petani yang dapat menunaikan ibadah haji, menguliahkan anak-anaknya dan membeli kendaraan. Melanjutkan usaha sayuran merupakan tanggungjawab generasi, disamping tanggungjawab sosial untuk melindungi ribuan tenaga kerja yang menggantungkan hidupnya pada sayuran.

Berbeda dengan pelaku primer, pelaku sekunder memiliki konsep diri yang mandiri (autonomous), lebih dipengaruhi nilai-nilai luar yang dipandangnya sesuai dengan kondisi lingkungan setempat (eksternalisasi).
Menurutnya, sayuran tidak tepat diusahakan secara intensif pada lahan konservasi. Ada usaha alternatif yang lebih cocok dan ramah terhadap lingkungan konservasi. Konsekuensinya, karena aktifitas mereka relatif tidak sejalan dengan petani pada umumnya, maka perilakunya dianggap menyimpang (deviant). Dukungan terhadap mereka justru datang dari luar, terutama dari pemangku kehutanan dan komunitas peduli lingkungan. Kelompok rujukannya adalah lembaga swadaya masyarakat, organisasi peduli lingkungan dan komunitas hijau. Kecenderungannya, konsep diri, significant others dan reference group pelaku brain gain primer berbeda dengan pelaku sekunder (Gambar 4).

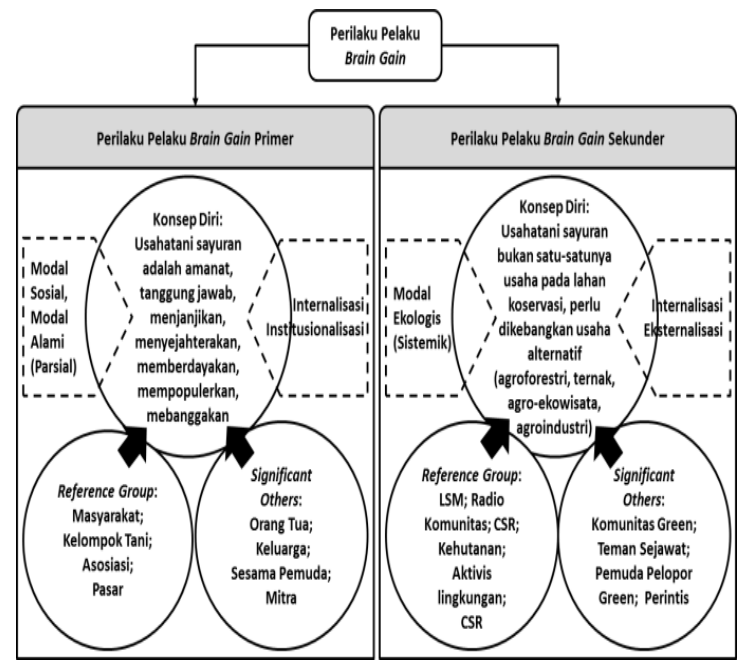

Gambar 4. Model Pembentukan Konsep Diri Pelaku Brain Gain

Bagipelakubraingain sekunder, apayang dilakukannya dapat dikatakan sebagai produk intensi, artinya apa yang dilakukan pelaku (baik agribisnis non sayuran maupun yang berkaitan dengan pelestarian lingkungan) merupakan suatu kebulatan tekad untuk menghasilkan keadaan tertentu di masa depan. Sedangkan apa yang dilakukan oleh pelaku brain gain primer cenderung sama dengan apa yang dilakukan oleh para pendahulunya, yakni berorientasi ekonomi. Pandangan pelaku brain gain primer memang ada unsur futuristiknya, tetapi tindakannya belum terlepas dari pengaruh orientasi masa lalu yang konservatif dan warna dominan komoditas, disamping minimnya orientasi pada keberlanjutan ekologis.

\section{Dimensi Kemandirian Pelaku Brain Gain}

Kemandirian adalah kemampuan mengakomodasikan sifat-sifat baik manusia untuk ditampilkan dalam sikap dan perilaku yang tepat berdasarkan situasi dan kondisi yang dihadapi oleh seorang individu (Sumardjo, 1999). Steinberg (2001) menjelaskan bahwa kemandirian dapat diidentifikasi dari dimensi-dimensinya, seperti emosi, perilaku, nilai, kerjasama, ekonomi, kewirausahaan, materil, intelektual, pembinaan dan ekologis. Pada umumnya, pelaku brain gain di dataran tinggi Cianjur relatif mandiri dalam wirausaha, kerja sama dan emosi. Secara ekonomi, sebagian besar usaha pelaku 
brain gain masih bias agribisnis sayuran dataran tinggi, tergantung pada musim dan tergantung pada sumberdaya milik keluarga. Usahanya sudah terpola, tetapi belum terencana. Pada beberapa pelaku, produksi sudah mulai mengacu pada permintaan pelanggan, namun sebagian besar masih berpola rutinitas.

Secara umum, kemandirian sosial, ekonomi, emosi dan perilaku para pelaku brain gain sudah tinggi, baik untuk pelaku primer maupun sekunder (Gambar 5). Namun, kemandirian ekologis pelaku brain gain primer masih tergolong lemah. Indikatornya teridentifikasi dari aplikasi input kimia yang belum sesuai dosis. Sayuran organik telah diadopsi oleh beberapa pelaku, tetapi skala dan intensitasnya masih terbatas. Secara historis, upaya internalisasi budaya tani sayuran organik sejatinya diinisiasi oleh para pelaku brain gain sekunder. Terkait dengan kemandiriannya, kedua pelaku brain gain baru terlihat nyata pada sisi keberdayaan personal, sedangkan kemampuan interelasi dan interdependensinya belum kuat. Hal itu terlihat dari masih statisnya kelompokkelompok pelaku agribisnis dan minimnya eksistensi pelaku muda dalam penyuluhan dan berbagai aktivitas kelembagaan pedesaan.

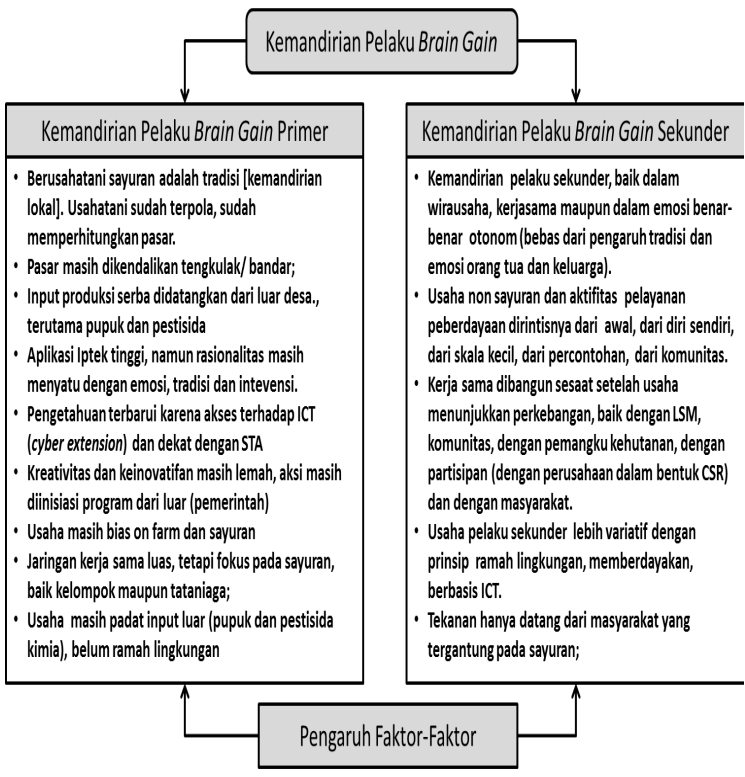

Gambar 5. Kecenderungan Kemandirian elaku Brain Gain

Benar bahwa beberapa pelaku brain gain primer telah tertautkan dengan perusahaan benih, perusahaan obat, perusahaan alat mesin pertanian, supplier, subterminal agribisnis, hotel, restauran, supermarket dan eksportir, namun posisi tawar mereka masih tetap lemah. Kecenderungannya, para pelaku brain gain primer sangat tergantung terhadap input (benih, pupuk dan pestisida) yang diproduksi oleh perusahaan. Jejaring pasar yang terbangun baru ternikmati oleh sedikit pelaku agribisnis, terutama individu petani berlahan luas, bandar, supplier dan eksportir. Volume produksi yang terserap oleh pasarpasar alternatif baru sekitar 10 persen, sedangkan 90 persennya masih mengalir ke tengkulak, bandar, pasar tradisional dan pasar induk. Begitu juga para pelaku brain gain sekunder, meskipun jaringannya luas, tetapi sifatnya masih individual. Jejaring pasar dan informasinya sudah berbasis teknologi informasi (cyber), tetapi lemah sisi institusinya. Kemodernan diadopsi oleh pelaku primer, sedangkan kualitas sumberdaya lokal dan lingkungan diabaikan.

\section{Faktor Pendorong dan Penarik Brain Gain}

Faktor pendorong brain gain cenderung berbeda antara pelaku brain gain primer dengan pelaku brain gain sekunder. Pelaku primer cenderung terdorong oleh faktor selesai sekolah, selesai magang, putus sekolah, melanjutkan usaha keluarga, memberdayakan masyarakat desa dan mengembangkan agribisnis. Selain itu, terdorong juga oleh keluarga, komunitas pemuda, reference group dan program pemerintah. Sedangkan tindakan pelaku brain gain sekunder lebih terdorong oleh orientasi pelestarian lingkungan, menciptakan lapangan kerja alternatif di kawasan konservasi, membangun desa, memberdayakan masyarakat, mengentaskan kemiskinan dan menerapkan Iptek. Pelaku sekunder cenderung lebih kreatif, sehingga warna faktor pendorong internalnya lebih dominan dibanding faktor pendorong eksternalnya (Gambar 6). Kecenderungannya, baik pelaku brain gain primer maupun sekunder dipengaruhi tren global (seperti biotechnology, pasar modern, produk korporasi, komoditas impor, pertanian organik, perubahan iklim, back to nature, green dan aplikasi teknologi komunikasi dan informasi [radio komunitas, cyber extension]).

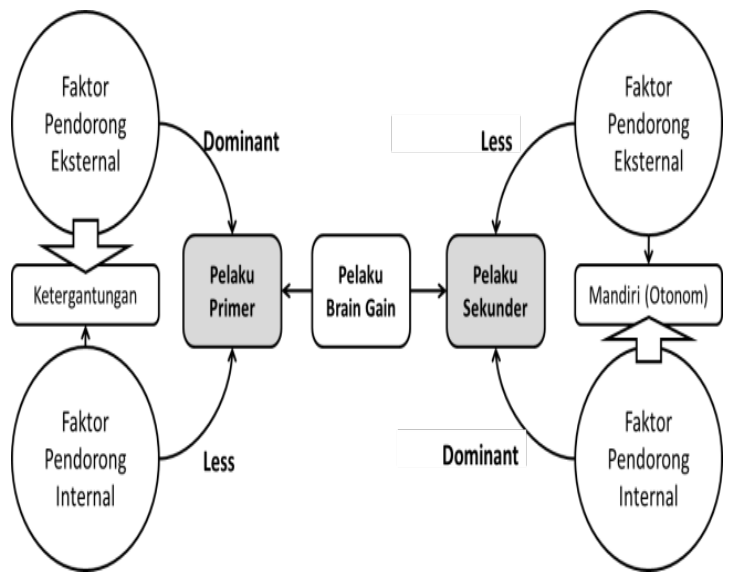

Gambar 6. Model Keterkaitan Faktor Pendorong Brain Gain pada Pelaku Primer dan Sekunder

Penelitian Liu (2005) dan Warker (2009) mengungkap bahwa keputusan para pelaku brain gain dipengaruhi juga oleh faktor penarik, baik faktor struktural maupun faktor sosio-kultural. Faktor struktural meliputi harga komoditas, perkembangan pasar, insentif, perbaikan fasilitas pedesaaan, penempatan kerja, program pembangunan, permintaan pihak ketiga, tersedianya peluang kerja/usaha, membaiknya akses sumberdaya produktif dan jasa layanan di daerah. Sedangkan faktor sosiokultural dan naturalnya adalah potensi SDA, kondisi alam pedesaan, komoditas, kepercayaan masyarakat, amanat 
orang tua/keluarga untuk melanjutkan usaha dan budaya tani. Termasuk dalam faktor struktural adalah kebijakan pemerintah (seperti pendampingan, sarjana membangun desa).

Faktor penarik cenderung berbeda antara pelaku primer dengan sekunder (Gambar 7). Kecenderungannya, pelaku brain gain primer lebih tertarik faktor struktural, seperti harga komoditas, perkembangan pasar sayuran (retail, subterminal agribisnis, hotel dan restaurant), ketersediaan aset keluarga (terutama lahan), potensi SDA, eksistensi kelompok dan keluarga. Faktor sosio-kultural juga berpengaruh, tetapi lebih pada fungsi lingkungan sebagai ruang usaha ekonomi, bukan ruang ekologisnya. Sedangkan pelaku brain gain sekunder cenderung tertarik oleh faktor sosio-kultural dan faktor natural, yakni memperbaiki kondisi alam pedesaan yang rusak. Lingkungan lebih dilihat sebagai ruang ekologis yang berfungsi konservasi daripada sebagai ruang ekonomi. Oleh karena itu, perilaku pelaku brain gain sekunder lebih mengedepankan usaha perlindungan lingkungan daripada maksimalisasi produksi. Dalam kerangka usahatani pun, pelaku sekunder lebih mengedepankan pendekatan agribisnis ekologis, seperti agroindustri dan agroforestri.

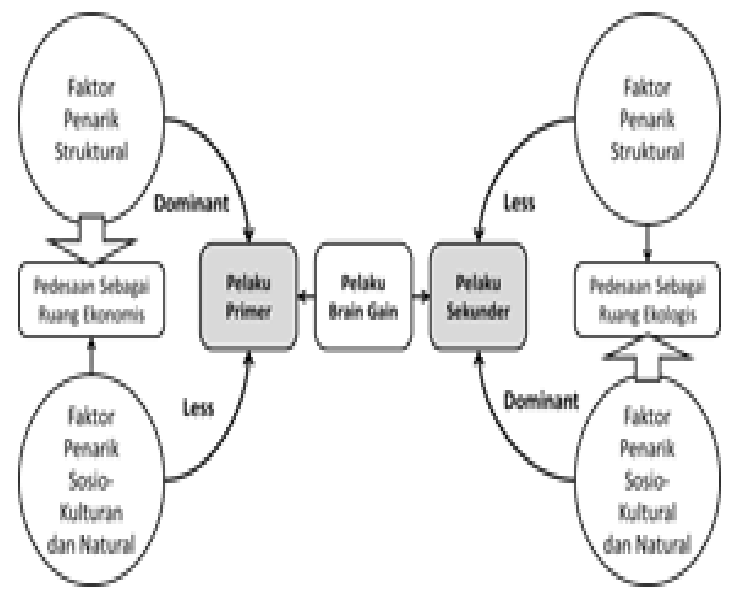

Gambar 7. Model Keterkaitan Faktor Penarik Brain Gain pada Pelaku Primer dan Sekunder

Bagi pelaku sekunder, dataran tinggi tidak hanya cocok untuk usahatani sayuran, tetapi juga untuk agroforestri dan ekowisata. Ketua Kelompok Tani Hutan (KTH) menyatakan: "bagi kami, manfaat ekonomis kedua model usaha alternatif tersebut bukan hanya keuntungan ekonomi dari hasil penjualan produk, tetapi juga nilai jual ekologis dan nilai jual pelayanan; apalagi banyak melibatkan pemuda dalam pengelolaan ekowisata, terutama dalam outbound dan camping ground di blok Pasir Sarongge. Manfaat lainnya yang bersifat intangible adalah pendidikan dan penyadaran kepada masyarakat akan pentingnya lingkungan". Keberadaan radio komunitas juga bernilai informatif dan pendidikan bagi masyarakat dataran tinggi. Jika dikaitkan dengan temuan Faiz (2005) di China dan India, maka dapat ditegaskan bahwa faktor penarik sumberdaya alam (ekologis) menjadi yang dominan bagi kedua pelaku brain gain, sedangkan yang menjadi pengahambat adalah kondisi jalan dan sarana transportasi yang belum memadai.

Secara umum, jalan, angkutan, pusat pelatihan, pusat penelitian, agroindustri, dan sarana pendidikan belum disipakan sebagai daya tarik brain gain oleh para pelaku kebijakan. Padahal, brain gain di China dan India diawali dengan menciptakan daya tarik internal negara, mulai dari level nasional hingga desa. Dengan demikian, para pelaku brain gain dapat mengaktualisasikan ilmu pengetahuan, teknologi dan keahliannya di daerah asal mereka. Fasilitas yang disediakan merupakan bentuk lain dari insentif non tunai yang diberikan negara kepada para pelaku brain gain. Friedman (2009) menegaskan bahwa untuk menarik pelaku brain gain, pemerintah China telah mengkreasi institusi penelitian hingga tingkat desa dan membangun mutu sistem pendidikan sampai tingkat desa. Bahkan, kurikulum di pedalaman China sama sulitnya dengan di Kota New York.

\section{Model Intervensi Brain Gain}

Penguatan pelaku brain gain di dataran tinggi Cianjur dapat dilakukan melalui integrasi nilai-nilai positif dari internal pelaku brain gain dengan nilai-nilai positif dari faktor penarik dan pendorongnya. Kelemahan pelaku brain gain dapat dikuatkan dan kelebihan-kelebihannya dapat ditingkatkan. Dengan demikian, modal potensial (sosial, ekonomi, alami dan informasi) pelaku brain gain primer dapat dilengkapi modal ekologis. Begitu juga pelaku brain gain sekunder yang lebih kuat sisi modal ekologis, sosial, alami dan informasinya dapat dilengkapi dengan modal ekonomi (Gambar 9). Model integrasi ini potensial bagi inisiasi dan inovasi regenerasi petani.

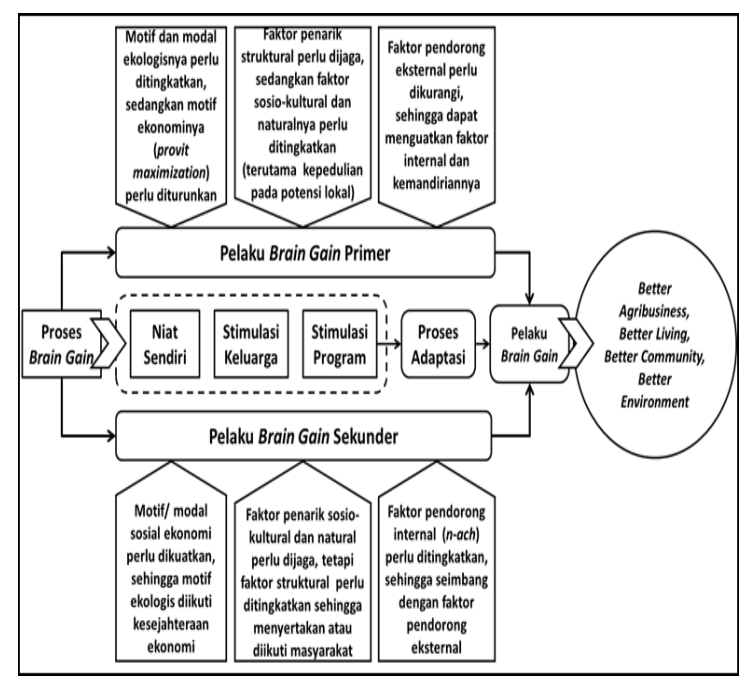

Gambar 9. Model Inovasi Brain Gain

\section{SIMPULAN}

Berdasarkan tujuan dan pembahasan, maka dapat ditarik kesimpulan sebagai berikut: (1) brain gain terjadi karena adanya niat sendiri (swakarsa), stimulasi keluarga dan program pemerintah maupun swasta. Ada kategori pelaku 
brain gain primer (on-farm, terutama sayuran) dan kategori sekunder (off-farm sayuran dan non farm). Motif keduanya berbeda, tetapi sama-sama melalui proses adaptasi dengan tujuan better agribusiness, better living, better community dan better environment; (2) karakteristik kedua pelaku relatif berbeda, terutama motivasi dan orientasinya. Pelaku primer mewarnai wirausaha agri-bisnis sayuran, sedangkan pelaku sekunder mewarnai wirausaha agribisnis non sayuran dan non-farm; (3) perilaku pelaku primer fokus pada usahatani sayuran dan lebih melihat potensi desa dari perspektif ekonomikal, sedangkan pelaku sekunder menempatkan agribisnis (sayuran dan non-sayuran) secara utuh sebagai entitas lingkungan (perspektif ekologikal); (4) kedua pelaku relatif mandiri dalam wirausaha, kerjasama dan emosi. Kemandirian wirausaha pelaku primer cenderung pada sayuran, sedangkan yang sekunder pada non sayuran. Kemandirian pelaku primer lemah secara ekologis, sedangkan pelaku sekunder lemah secara ekonomis; (5) pada pelaku primer, faktor pendorong eksternal lebih dominan, sehingga pelaku cenderung ketergantungan. Sedangkan pada pelaku sekunder, faktor pendorong internal lebih dominan dibandingkan faktor pendorong eksternal, sehinggga pelaku cenderung lebih otonom dalam berwirausaha. Brain gain terjadi karena faktor penarik struktural dan kultural. Pada pelaku primer, faktor struktural lebih dominan, sehingga pelaku memandang pedesaan sebagai ruang ekonomis. Modal sosialnya kuat, namun lemah modal ekologisnya. Pendekatan usahanya parsial dan homogen. Sedangkan pada pelaku sekunder, faktor kultural lebih dominan, dan kuat sisi modal ekologisnya. Usahanya berkelanjutan dan divergen, namun lemah secara ekonomi; dan (6) model brain gain memungkinkan dibangun dengan memadukan nilai-nilai positif dan produktif dari model brain gain primer dengan model brain gain sekunder, dengan menguatkan faktor pendorong dan penarik yang masih lemah dan meningkatkan faktor pendorong dan penarik yang sudah berjalan. Kehadiran pelaku brain gain terbukti membawa perubahan di dataran tinggi Cianjur, oleh karena itu dapat direkomendasikan sebagai pendekatan inovasi regenerasi pelaku agribisnis. Namun, perlu dilakukan kajian lanjutan terkait dengan kesiapan beragribisnis kedua pelaku brain gain.

\section{DAFTAR PUSTAKA}

Agussabti. 2002. Kemandirian Petani dalam Pengambilan Keputusan Adopsi Inovasi: Kasus Petani Sayuran di Jawa Barat. Disertasi. Sekolah Pascasarjana IPB, Bogor.

Beine, M., F. Docquier and H Rapoport. 2008. Brain Drain and Human Capital Formation in Developing Countries Winners and Losers. Economic Journal, 118,528
Capra, Fritjof. 2002. Jaring-Jaring Kehidupan: Visi Baru Epistemologi dan Kehidupan. Alih Bahasa oleh Saut Pasaribu. Fajar Pustaka, Yogyakarta

Collier, WL., Santoso K., Soentoro dan Wibowo R. 1996. Pendekatan Baru dalam Pembangunan Pedesaan di Jawa: Kajian Pedesaan Selama Dua Puluh Tahun. Yayasan Obor Indonesia, Jakarta.

Faiz, P.M. 2007. Brain Drain dan Sumber Daya Manusia Indonesia: Studi Analisa terhadap Reversed Brain Drain di India. Faculty of Law, University of Delhi. School of Social Science, IGNOU, New Delhi

Friedman, T.L. 2009. The World is Flat: Sejarah Ringkas Abad Ke-21. Dian Rakyat, Jakarta.

Hunger, Uwe. 2002. The "Brain Gain" Hypothesis. Third World Elites in Industrialized Countries and Socioeconomic Development in their Home Country. The Center for Comparative Immigration Studies (CCIS) University of California, San Diego.

Konferensi Uni Eropa. 2007. Human Capital in European Peripheral Regions Brain Drain and Brain Gain. Summary of the Conclusions for the end Conference, Switzerland, 14-15 June 2007

Kupets, Olga. 2011. Brain Gain Or Brain Waste? The Performance Of Return Labor Migrants In The Ukrainian Labor Market. This project was supported by the Economics Education and Research Consortium and funded by GDN.

Kurnia, G. 1995. Menetaskan Pemuda, Mengentaskan Kemiskinan. Majalah Prakarsa Edisi I Tahun 1995. Pusatat Dinamika Pembangunan Unpad, Bandung.

Mahbubani, K. 2011. Asia Hemisfer Baru Dunia: Pergeseran Kekuatan Global ke Timur yang Tak Terelakan. Penerbit Kompas, Jakarta.

Sadono, D. 2012. Model Pengembangan Keberdayaan Petani dalam Pengelolaan Usahatani Padi: Kasus di Jawa Barat. Disertasi. Sekolah Pascasarjana IPB, Bogor.

Schiff, S. 2005. Brain Gain: Claims About its Size and Impact on Welfare and Growth are Greatly Exaggerated. Forschungsinstitut zur Zukunft der Arbeit Institute for the Study of Labor.

Setiawan, I. 2012. Agribisnis Kreatif: Pilar Wirausaha Masa Depan Kekuatan Dunia Baru Menuju Kemakmuran Hijau. Penebar Swadaya, Jakarta.

Soewardi, H. 1978. Respon Masyarakat Desa Terhadap Modernisasi Produksi Pertanian Terutama Padi. UGM Press, Yogyakarta. 
Stark, O. 2004. Rethingking The Brain Drain. The World Development. Volume 32 Nomor 1 (15-22.

Steinberg L. 2001. Adolescence-Third edition. New York: Mc.Graw Hill, Inc.
Sumardjo. 1999. Transformasi Model Penyuluhan Pertanian Menuju Pengembangan Kemandirian Petani: Kasus di Provinsi Jawa Barat. Disertasi. Sekolah Pascasarjana IPB, Bogor. 